\title{
Financial literacy and financial literacy programs in Australia
}

\author{
Andrew C. Worthington \\ is Professor of Finance at Griffith University in Brisbane, Australia. His research and consulting activities, for which he has received \\ numerous grants and awards, include household financial decision-making, risk attitudes, and portfolio diversification, with relevant \\ studies published in the Journal of Consumer Policy, Financial Services Review, Journal of Family and Economic Issues, Studies in \\ Economics and Finance, International Journal of Housing Markets and Analysis, Review of Economics of the Household, International \\ Journal of Consumer Studies, and the Financial Counselling and Planning Journal.
}

\begin{abstract}
Financial services markets require consumers to be more financially literate if they are to manage their finances effectively. Consequently, there have been an increasing number of attempts to measure financial literacy, as variously defined, and in response to observed deficiencies in financial literacy, an expanding number of financial literacy programs implemented worldwide, not least in Australia. The purpose of this paper is twofold. First, review the existing evidence on the level of financial literacy in Australia, along with the posited determinants and potential impacts on consumers and the marketing of financial services. Second, discuss the financial literacy programs currently in place in Australia aimed at increasing the level of financial literacy across the population as a whole and in specific groups set in place by government, industry, community, and workplace initiatives. The paper includes brief critiques of the process of measuring, assessing, and understanding financial literacy as it stands and the purpose, design and evaluation of the financial literacy programs currently in place.
\end{abstract}

Keywords: financial literacy; financial literacy programs; Australia 


\section{INTRODUCTION}

Over the past two decades, interest in financial literacy has increased massively worldwide. One result has been a proliferation in the volume of research undertaken into financial literacy by government, industry, and community organizations. At the same time, there has been on-going and burgeoning interest in financial literacy programs by these same bodies, aimed at redressing some of the deficiencies in financial literacy they and others have found. Similar developments are evident in Australia, where regulators, industry associations, individual businesses (especially financial institutions), community groups, and not least, academic researchers, have all taken a keen interest in this important area.

One problem facing Australia's many financial literacy stakeholders is the sheer volume of the published and unpublished material available on the measurement and level of financial literacy for which no concise review currently exists. It is also difficult to attain a good understanding of the myriad programs currently operating, particularly in terms of their target groups and program objectives. Accordingly, the purpose of this paper is twofold. First, review the existing findings on financial literacy in Australia, along with its purported determinants and potential impact on consumers and the marketing of financial services. The emphasis here is on describing where we have gained our knowledge of financial literacy in Australia.

Second, discuss programs currently in place aimed at increasing the level of financial literacy across the population as a whole and in specific groups set in place by government, industry, community, and workplace initiatives. The focus here is conveying to the reader the diversity of financial literacy programs in place in Australia and the population groups targeted given the knowledge of financial literacy gained earlier. The paper also provides a brief critique concerned with measuring, assessing, and understanding financial literacy and the models used for the systematic evaluation of financial literacy programs. This helps to guide future research in this area.

Importantly, the purpose of this paper is not to provide a literature review of academic research into Australian financial literacy. Its rather broader objective is to discuss the existing state of knowledge of financial literacy and financial literacy programs, which in nearly all cases is available from government, industry, and nongovernment organisation reports and websites, not published academic research. This provides a snapshot for financial literacy stakeholders [including policymakers, charities, industry and professional associations, trade unions, financial and nonfinancial firms, financial and consumer services 
advisors, schools and further education institutions, and researchers] interested in better understanding the Australian financial literacy context as a necessary starting point for their own work. For this reason alone, the paper is necessarily general, with all that entails.

The remainder of the paper is divided into four sections. The first section briefly places financial literacy in Australia in context, in relation to both developments in comparable economies and within Australia. The second section discusses the various governmental, industry and other reports concerning the definition, measurement, and level of financial literacy in Australia. The third section examines a sample of the financial literacy programs currently in place. The paper ends with some brief concluding comments.

\section{THE INTERNATIONAL CONTEXT}

Starting with the U.S., the U.S. Federal Reserve Board-founded Jumpstart Coalition for Personal Financial Literacy (2013) has since the early 2000s biannually surveyed the financial literacy of high school students, and one response has been the proliferation of state legislation mandating financial literacy in school curricula. More recently, the U.S. Senate Committee on Banking, Housing, and Urban Affairs conducted hearings into the state of financial literacy and education and the U.S. Department of Treasury (2012) created the Financial Literacy and Education Commission with a specific focus on improving national financial literacy.

Likewise, there has been on-going and burgeoning interest in financial literacy programs by businesses in the U.S., especially financial institutions. In evidence, Blanton (2011) identified in excess of four thousand websites providing financial education and financial decision tools serving diverse online communities! The Consumer Bankers Association's (2005) Survey of Bank-Sponsored Financial Literacy Programs irregularly assesses some of these programs. In addition, the Consumer Bankers Association is also a participant in several key financial literacy initiatives. These include the Credit Fairy campaign helping consumers improve their credit scores, an America Saves Week aimed at improving knowledge of saving, Hit the Books Running focused at early planning for parents and college students lessen the burden of student debt, and the HOPE NOW and Project Lifeline campaign to increase financial literacy among possibly defaulting mortgage borrowers.

In the U.K., as early as 2003 the Financial Services Authority called a summit of industry leaders and consumer activists to develop a strategy to advance consumer education, 
information, and generic financial advice. This has manifested itself most notably in 2010 as the Consumer Financial Education Body (now The Money Advice Service), an independent body that promotes personal financial literacy. Several other longstanding financial literacy programs also operate in the U.K. For example, the Personal Finance Education Group (2013) aims to raise the competence of personal finance educators, while the Citizen's Advice Bureaux (2013) seeks to increase the level of financial knowledge in the broader community. Other financial literacy initiatives throughout the world include financial literacy programs implemented by the Financial Consumer Agency of Canada (2013) and the Canadian Bankers Association's (2005) Building a Better Understanding program and the New Zealand Retirement Commission (2013) and the New Zealand Financial Literacy Programme developed by Enterprise New Zealand Trust (2005).

These major government and industry initiatives, of course, do not include the countless financial literacy programs initiated, sponsored, and funded by hundreds of individual community groups and workplaces in these countries, sometimes in partnership with government and/or industry associations. They also do not reflect the efforts by various intergovernmental bodies to promote financial literacy and coordinate national financial literacy programs. These include, most notably, the World Bank (Xu and Zia, 2012) and the Organisation for Economic Cooperation and Development (OECD) (2005, 2012), with both surveying existing national programs, providing guidance on the direction national financial literacy strategies should develop in the future, and in the case of OECD (2012), a pilot study comparing international financial literacy. It also includes the OECD (2013) in developing an international financial education knowledge gateway and coordinating inputs into school curricula and a consistent assessment framework through its Programme for International Student Assessment (PISA) (OECD, 2012).

In Australia too, a number of government and industry reports have highlighted the need to better understand and improve financial literacy. The Australian Law Reform Commission's (2005) Seen and Heard report very early found that young people were ill informed about a wide range of consumer services. Since then, the ANZ's (2003, 2005, 2008, 2011) triennial Survey of Adult Financial Literacy in Australia has consistently shown that while most Australians have basic financial literacy, young consumers and those from low socioeconomic backgrounds were at a disadvantage in making informed decisions about money management. Similarly, the Australian Securities and Investments Commission's (ASIC) (2005) Financial Literacy in Schools report championed financial literacy programs inside and outside of schools, while the Consumer and Financial Literacy Taskforce's (2004) 
Australian Consumers and Money provides a stocktake of initiatives by public, private and community sector bodies.

Other reports, of both government and nongovernment origin, relevant to our understanding of financial literacy in Australia include the Financial Literacy Foundation (FLF) (2007, 2008), National Australia Bank (NAB) (2011) and the Commonwealth Bank Foundation (CBF) $(2004,2006)$. There is also a small but rapidly growing body of academic research in this area including, among others, Garman et al. (1999), Beal and Delpachtra (2003), Brown et al (2004), Marcolin and Abraham (2006), Worthington (2006, 2008), Cardak and Wilkins (2009), Fry et al (2008), Samy et al (2008), Gerrans et al (2009), Tennant et al (2009), Wagland and Taylor (2009), Croy et al (2010), Gallery et al (2011), Taylor and Wagland (2011), Sandlant (2011) and Bateman et al (2012).

\section{FINANCIAL LITERACY IN AUSTRALIA}

\section{Definition}

For the most part, the definition of financial literacy most commonly used in Australia is that employed in the triennial series of national adult financial literacy surveys conducted by the ANZ since 2003 (ANZ 2003, 2005, 2008, 2011) where financial literacy is: "The ability to make informed judgements and to take effective decisions regarding the use and management of money". Derived from a U.K. report to the Natwest Group Charitable Trust (Schagen and Lines, 1996), this definition has been subsequently adopted by nearly all financial literacy reports in Australia, most notably ASIC (2011) [and before then, its predecessor in the role, the $\operatorname{ALF}(2007,2008)]$, the regulatory body tasked with implementing the National Financial Literacy Strategy. Of course, there is much unsaid in this rather modest definition. For example, the ANZ surveys agreed that financial literacy was about people becoming confident decision makers in all aspects of their budgeting, spending and saving, but that measures of financial literacy should reflect individual circumstances, and were therefore relative. As such, knowledge was “...only to be tested against an individual's needs and circumstances rather against the entire array of financial products and services, some of which they will neither use nor need" (ANZ, 2003).

Likewise, ASIC (2011) has more recently conceded that this definition acknowledges that financial literacy means more than just understanding how things work and that it therefore encompasses making good choices and applying them. In this sense, ASIC (2011) argued that the concept of 'financial literacy' prevailing in Australia actually related more to 
the U.K. term 'financial capability' in terms of acting on knowledge gained, but 'financial literacy' as a term was now firmly embedded in policy and practice. Elsewhere in the reports relevant to financial literacy, its definition is consistent with that ultimately enshrined in the National Financial Literacy Strategy [see, for example, CBF (2004a, 2004b)], though often with some qualification. For example, the Australian Bankers' Association (ABA) (2013) pointed out that "Financial literacy is not just about numeracy - even if we are good with numbers we might not be good at managing our money. Financial literacy is about people gaining a practical understanding of financial matters and the consequences of their own behaviours that will affect their financial well-being”, while NAB (2011) like ASIC (2011) recognised the parallels in the use of the term 'financial literacy' alongside 'financial capability' in discussing demand-side factors affecting financial exclusion. Nonetheless, it is clear that the definition of financial literacy commonly used in Australia is mostly consistent with that commonly applied by intergovernmental bodies like the World Bank and the OECD (2011).

\section{Level and determinants}

Three sets of large-scale surveys of financial literacy have been undertaken in Australia to date, two by financial institutions, the ANZ Bank (2003, 2005, 2008, 2011) and the Commonwealth Bank through the CBF $(2004,2006)$, and one by a Commonwealth government-funded agency, the FLF $(2007,2008)$ whose responsibilities subsequently shifted to ASIC in 2008.

Roy Morgan Research conducted Australia's first national survey of financial literacy on behalf of ANZ in 2003. This consisted of two parts: a telephone survey of 3,548 adults alongside an in-depth survey of 202 adults consisting of a self-completion component and an interview. In general, the finding of this first ANZ survey were that persons with low levels of financial literacy were also characterized by low levels of educational attainment, income and employment, were frequently younger and mostly single, and possessed less than average levels of debt and savings. By the 2008 ANZ survey (now conducted by the Social Research Centre at the University of NSW), the results once again pointed to a strong relationship between financial literacy and individual socioeconomic and demographic characteristics (ANZ, 2008). Reflecting this link with socioeconomic disadvantage, scores were also lower among the unemployed, low-level blue-collar occupations, those whose main source of income was a government benefit or allowance or with household incomes less than $\$ 25,000$ per annum, those who spoke a language other than English at home, and the Indigenous. 
Conversely, financial literacy scores were significantly higher for persons aged 35-59 years, males, those who had completed a university degree, high-level white-collar occupations, and those whose annual household income was at least $\$ 150,000$ per annum.

The 2008 survey also commented on behaviours linked with better financial literacy, including the use of many and diverse information sources, obtaining advice from an accountant, tax specialist, or financial planner, shopping around for alternate products and the use of online financial calculators (ANZ, 2008, p. 3). By the fourth and most-recent survey in 2011 of 3,502 respondents (now again by Roy Morgan Research), financial literacy was now envisaged as consisting of five separate components: keeping track of finances, planning ahead, choosing financial products, staying informed, and financial control, with separate financial literacy indices calculated for each component. While the results were consistent with earlier findings, they also evidenced the rapid uptake of electronic banking and access to internet-based sources of financial information.

Soon after the first ANZ survey, the CBF (2004) conducted a telephone survey of 5,000 Australians in partnership with Eureka Strategic Research and the Centre of Policy Studies at Monash University. The results found that the 10 per cent of the population with the lowest financial literacy were more likely aged between 16 and 20 years, male, unemployed or students, and have lower levels of education and personal and household income. A subsequent survey, CBF (2006), required 50,000 Year 9/10 students from 500 schools across Australia to complete an objective assessment task comprising 48 multiple-choice questions related to everyday financial situations. The findings indicated that no more than 50 per cent of students were able to understand any single basic financial literacy concept, mostly comprising matters relating to the use of bank deposits and credit cards.

The final major source of information on financial literacy in Australia is from a survey of 7,500 Australians aged 12 to 75 years conducted by the FLF (2007). This telephone survey obtained the responses to a series of questions regarding attitudes to money and money management behaviour across 7 topics (budgeting, saving, investing, credit and debt, planning and retirement, protecting money, and information and advice) and 13 corresponding money management issues. This survey identified that there was not one but many possible paths to financially literate behaviour and better financial outcomes, representing different life experiences, abilities, attitudes, beliefs and behaviours. In FLF (2008) the responses to this survey were re-examined to more closely focus attention on the attitudes and behaviours of the subsample of 4,138 women when it came to using and managing money. 
Apart from these large-scale national surveys of financial literacy in the Australian population, a number of smaller surveys have also thrown useful light on financial literacy in Australia. In very early work, Beal and Delpachitra (2003) surveyed first-year students across a number of faculties at the University of Southern Queensland and tested skills and knowledge in basic financial concepts, financial markets and instruments, planning, analysis and decision-making, and insurance. Later, Worthington (2006) used the underlying data in the 2003 ANZ Survey to address more closely the determinants of financial literacy in a multivariate framework. Factors examined include gender, age, ethnicity, occupation, education, income, savings, and debt, with the results indicating higher financial literacy for persons aged between 50 and 60 years, professionals, business and farm owners, and university/college graduates. Literacy was found to be lowest for the unemployed, females, and those from a non-English speaking background with a low level of education. A similar approach was later applied in Worthington (2008) to specific financial knowledge relating to superannuation (private retirement income) using a subset of 2,516 superannuation fund members, this time from the 2005 ANZ Survey.

In other work, Tawfik et al. (2008) surveyed university students, but not so much with the intention of measuring the level of financial literacy, rather the basic financial knowledge of key products common to youth in Australian society. Likewise, Tennant et al. (2009) used data collected from 1,265 individuals who sought substantive financial counselling assistance from Anglicare Victoria in Gippsland, Victoria between 2001 and 2004 as a means to establish a link between financial literacy and 'financial hardship'. University students again provided the sample when Wagland and Taylor (2009) surveyed 165 undergraduate students at the University of Western Sydney in 2004. The results here indicated that 74 per cent of respondents were able to answer correctly most questions displaying a reasonable level of general personal financial knowledge. In a final Australian survey, Gerrans et al. (2009) surveyed 48 Indigenous respondents in Perth. The results suggested that some areas of financial knowledge were significantly weaker for this population subgroup.

\section{Critical analysis}

To varying degrees, these studies have made a positive contribution to our understanding of the level and determinants of financial literacy in Australia. First, most Australians have reasonable levels of financial literacy and mostly feel confident about their knowledge of financial issues. Second, nearly all Australians appear to know and understand simple day-today money management concepts like budgeting, credit, savings and debt, but struggle with 
more complex concepts like investments, superannuation, and saving for retirement. Third, mostAustralians appear open to the benefits of financial education, and rely on a wide range of information and advice services when researching financial decisions and/or trying to gain financial knowledge. These include informal (e.g. family and friends, the media) and formal (e.g. financial advisers, accountants and providers) sources. Finally, a large number of factors appear to influence financial literacy, including attitudes and beliefs about money, interest, confidence, and engagement in financial matters and socioeconomic and demographic characteristics (e.g. age, gender, education, income, and ethnicity).

A first major weakness is that surveys include only questions about financial products and services that respondents currently use or very basic financial products and services. While this ensures an appropriate context, it ignores the fact that consumers should also be informed about products and services in which they are yet to partake. Marcolin and Abraham (2006) argue that this is especially noticeable when comparing the findings of the ANZ surveys with the roughly coterminous CBF survey (2004), with the former exhibiting more positive results overall resulting in the appearance of higher levels of financial literacy among the Australian population.

A second major weakness is that most surveys employ subjective assessments, which rely on respondent's perceptions, attitudes, self-reported behaviour, and self-assessed level of financial knowledge. They therefore ignore objective assessments, which measure and test people's understanding of financial terms through, say, 'multiple-choice', 'true/false' or 'short-answer' questions. Nonetheless, even these sorts of questions do not very often link with the apparent ability to make good financial decisions as they merely test the level of financial knowledge (ASIC 2011). And in fact, the most accurate test of financial literacy would be in terms of the superiority of ex post financial decision-making, not the hypothesised ex ante ability to make good financial decisions.

As to the implications for the marketing of financial services, it is clear that financial literacy affects not only how consumers participate but also whether they engage particular services in the first instance. For example, while evidence suggests that persons with low levels of financial literacy use some types of services relatively unknown among those with higher levels of financial literacy, such as payday lending, they are also likely to engage in risky or less wealth-optimising behaviour in products or services commonly found across all levels of literacy. These including paying only the minimum payment on credit card balances, cash advances from credit cards, inadequate superannuation fund management, and poor choices relating to mortgage products. The major challenge for those concerned with the 
marketing of financial services is taking into account the great heterogeneity of consumers as it relates to financial literacy and recognise the inherent limitations of the concept of financial literacy itself.

\section{AUSTRALIAN FINANCIAL LITERACY PROGRAMS}

\section{Policy Framework}

The Commonwealth government is a major program funder of financial literacy programs in Australia. This accords well with the principal role of ASIC (2011, p. 8) as Australia's consumer protection regulator for financial services, bring with it "... regulatory tools to the task of improving Australians' financial wellbeing from communication, education and guidance through to enforcement action where required" (emphasis added).

In 2004, the Australian Government established a National Consumer and Financial Literacy Taskforce that recommended the establishment of the Financial Literacy Foundation in 2005, which was subsequently responsible for two of the major national surveys into Australian financial literacy (FLF 2007, 2008). In 2008, the functions of this foundation were transferred to ASIC, which after being informed by two of its own research reports, 'Financial Literacy in Schools' (ASIC 2005) and 'Financial Literacy and Behavioural Change' (ASIC, 2011a), duly set out its National Financial Literacy Strategy in ASIC (2011b).

In the National Financial Literacy Strategy, ASIC (2011b, p. 4) argued that financial literacy was a necessary and increasingly important skill, that there were disparities across the community, and that its improvement could improve economic performance and social inclusion and drive competition in the financial services sector. With this in mind, ASIC delineated four core elements of its strategy: (i) educational pathways to build financial literacy; (ii) provision of trusted and independent information, tools and support; (iii) recognition of the limits of education and information; and (iv) working in partnership and promoting best practice (ASIC, 2011b).

\section{Government programs}

In this paper, we define 'government' financial literacy programs as those principally financed, administered, and delivered by government departments or agencies. As discussed, ASIC is the regulatory body principally tasked with implementing the National Financial Literacy Strategy. At present, it does this directly through its MoneySmart website, which 
replaced its earlier FIDO (Financial Information Delivered Online) and Understanding Money websites, and a MoneySmart Teaching website. MoneySmart (2013) provides information, tools and calculators, printed guides and a helpline to assist consumers and investors in their personal finances, with separate pages targeting 'under $25 \mathrm{~s}$ ', 'over $55 \mathrm{~s}$, families, women and the Indigenous.

Other campaign initiatives of note are: MoneySmart Week, a series of money information events in partnership with business, government and community sector organisations (including achievements awards for business, government and community initiatives in financial literacy programs); a September 2011 Mortgage Health Campaign aimed at encouraging people to take action when experiencing mortgage stress; an October 2011 Unclaimed Money Campaign concerned with encouraging the search for lost money in ASIC's lost database of bank accounts, shares and life insurance policies; and a March 2012 Culturally and Linguistically Diverse Communities Campaign aimed at distributing money management kits in hardcopy to new Australians via settlement service providers and online in 26 languages. To date, three surveys have been used to evaluate the usefulness of the primary MoneySmart website, with the most-recent results indicating that 78 per cent of visitors found the site useful with another 90 per cent responding that they had taken some form of positive financial action because of visiting the site (ASIC 2012).

A secondary MoneySmart Teaching website provides professional learning resources to help both teachers and teacher educators to integrate financial literacy into secondary and further education teaching and learning programs. In addition, MoneySmart Teaching (2013) outlines an additional dimension into the government's role in financial literacy through its input in the Australian Curriculum and its on-going development by the Australian Curriculum, Assessment, and Reporting Authority (ACARA) (2013). ASIC's input into the new Australian Curriculum for Kindergarten to Year has professedly obtained the key result that in the new national mathematics curriculum there will be a Money and Financial Mathematics sub strand aimed at providing students with the mathematical knowledge and skills that underpin consumer and financial literacy. The supposed influence of ASIC is also apparent in the three current core learning areas (English, science and history) (ACARA, 2013) and in the draft economics and business curriculum (ACARA, 2012, p. 6).

Apart from ASIC, a number of other Australian government departments and agencies also provide financial literacy-related programs. For example, the Department of Human Services' (2013) Financial Information Service provides free education and information through seminars, by telephone or in person to enable informed decisions about investment 
and financial issues. Several other financial literacy programs are targeted specifically at the Indigenous. Elsewhere, the Department of Families, Housing, Community Services and Indigenous Affairs (FaHCSIA) (2013c) Indigenous Home Ownership program is aimed at developing financial skills in conjunction with a program concerned with encouraging home ownership for those able to obtain a long-term transferable lease on indigenous land and that can service a home loan. Lastly, FaHCSIA's Family Income Management (FaHCSIA 2013a) and Financial Management Program (FaHCSIA) provide information and ongoing support to help the Indigenous manage money, the latter concerned exclusively with those currently experiencing personal financial difficulties.

\section{Industry programs}

We define 'industry' financial literacy programs as those principally financed and provided by businesses, business foundations and business associations to customers and other persons. Of these, perhaps the most known is Saver Plus, an initiative of the ANZ and Brotherhood of St. Laurence, funded by ANZ and FaHCSIA, and delivered in partnership with The Smith Family, The Benevolent Society and Berry Street. In essence, Saver Plus is a combined matched savings and financial education program, established for assisting individuals on low incomes to develop a long-term savings habit (for the purpose of education expenses) and reach a savings goal.

One reason Saver Plus is so well known is that it is one of the few programs subject to rigorous evaluation. For the most part, these reports on program outcomes, including Fry et al (2008), Brotherhood of St. Laurence (2011a, 2011b), Russell et al (2011), reported not only positive improvements in saving behaviour but also in terms of accessing information on superannuation and investments, debt management and personal wellbeing and social connectedness. One of its chief funders, the ANZ, is also involved in conjunction with FacHSIA with MoneyBusiness, a kit and course used to deliver money management education in remote Indigenous communities, and some regional and urban areas.

Two other banks are involved in general financial literacy programs: the Commonwealth Bank through StartSmart and Westpac through the Davidson Institute (2013) in Financial First Steps. Launched in 2007, StartSmart initially was aimed toward teaching secondary students about financial literacy through experiences relevant their daily lives, including skills in earning, saving, spending and investing. This was extended to primary schools in 2010, employing a number of characters such as Captain SuperCents, Coach Cash and Gobbles the Wallet Monster, to educate young children about good spending habits. 
Finally, in February 2012, StartSmart launched Pathways, a workshop-based program aimed at the enhancing financial awareness among 18 to 25 year olds. In contrast, Financial First Steps includes short face-to-face courses, accredited training courses, free online learning and free local seminars aimed at a variety of groups, most notably Westpac employees, but also other employees and high school students. Most other Australian financial institutions also host and provide information relating to financial education, literacy, and inclusion, including the Bendigo Bank, the Bank of Queensland, Citibank Australia, HSBC and NAB. Lastly, the ABA's (2013) Broadening Financial Understanding program ostensibly works alongside and complements the programs of its member banks.

\section{Community programs}

In this paper, we define 'community' financial literacy programs as those including the participation of a community group, sometimes in a funding or delivery partnership with a government department and/or business. These include the Good Shepherd and Family Service (2013) Dollars n' Sense program and the provision of financial counselling alongside it and its co-partner National Australia Bank's No Interest Loans (NILS) and StepUp community-based programs aimed at providing interest-free and low interest loans to individuals or families on low incomes. It also includes Makingcents, a joint initiative by Citigroup Australia and YWCA NSW aimed at educating parents and teachers about developing good financial literacy skills in themselves and in their children.

Another community-based initiative includes the Financial Basics Foundation, a body established to help educate secondary students about responsible financial management practices launched in February 2002 in cooperation with the Bank of Queensland and Big Sky Credit Union. To date, Financial Basics has two programs relevant to financial literacy education. The first of these, Operation Financial Literacy, is a free ten-module teaching resource offered to schools. Introduced following a pilot program in 2002, and written by Australian business teachers, the modules include topics on financial planning, budgeting, credit and borrowing, financial protection and insurance, and saving and investing. A second initiative is ESSI Money, an online financial literacy game that enables participants to achieve an understanding of the basic concepts surrounding financial management, in the areas of Earning, $\underline{\text { Saving, }}$ Spending, and Investing (ESSI).

A final example of a community-based financial literacy program is that promoted by 10thousandgirl, a not-for-profit initiative of a group of young Sydney women that addresses the importance and long-term benefit of women having a financial plan and understanding 
finance basics through its Personal Finance Program. This is an interactive program aimed at delivering the principles of personal finance and investing through a 12-module course delivered through peer-run GIGs (Girl Investment Groups).

\section{Workplace programs}

We define 'workplace' financial literacy programs as those principally provided by businesses and other workplaces for their employees. Of these, we identify three upon which to elaborate: the Australian Defence Force's (ADF) Financial Services Consumer Council, the WA Department of Education's Into Your Comfort Zone, and Flight Centre's Moneywise Global. First, the Financial Services Consumer Council is an independent body concerned with developing good financial practices in ADF employees and their families both during and after their military career through a series of seminars, online guides and calculators. Of particular note is that this program earned a Highly Commended Award in the Workplaces category in the 2012 ASIC MoneySmart Week.

A second example of a workplace financial literacy program is Into Your Comfort Zone designed by the WA Department of Education in partnership with the WA Government Employees Superannuation Board. This program concerns educating teachers on complex financial concepts with the aims of retaining experienced teachers by introducing them to transition-to-retirement strategies and reinforcing flexible working policies, increasing employee understanding of wealth creation strategies to improve their retirement outcome, and empowering staff to make better financial decisions. A final example of a workplace financial literacy program is Moneywise Global (2013) a 1994 initiative of travel agency Flight Centre aimed at providing financial planning services for its employees, but also providing information on investing, superannuation, insurance, debt management, social security and retirement.

\section{Critical analysis}

It is first notable that many of the financial literacy programs in Australia appear at least notionally consistent with the National Financial Literacy Strategy. Second, many of these programs represent collaborative arrangements, often comprising one or more community groups working in association with a financial institution as a funding provider, along with input from a government or other body in terms of educational content and delivery. This is clearly an attractive model, but only time will tell if these programs continue or are able to survive the withdrawal of one or more of the partner organisations. Third, while many 
government and industry programs target the general population, very many others are concerned exclusively with groups commonly identified as having relatively low levels of financial literacy. Finally, it is common to see financial literacy programs delivered in conjunction with financial assistance and other programs aimed at enhancing financial independence in these target groups.

Even so, it is clear that the implementation of these financial literacy programs, while well meaning, seldom include very clearly defined objectives. It is also often unclear about who is demanding outcomes and against which criteria these will be assessed. Only a few appear to have been subject to rigorous post-program review and evaluation. This is especially the case for the large web-based financial information and training sites where much information is available but there is apparently little attempt to track the use of this information and the outcomes in terms of enhanced financial literacy. The question also presents itself whether the provision of, for example, fact sheets, and calculators actually represents a financial literacy program. Finally, it is also clear that many of the financial literacy programs supplement other social welfare initiatives, and it is not apparent which part is responsible for the improvement if any in financial literacy.

Overall, the research has repeatedly shown us that efforts to improve financial literacy have proven elusive. But unfortunately, the diversity of 'financial literacy programs' in place do little to reassure us that they have any sort of consistency of purpose and meet appropriate educational standards and are not merely a different sort of marketing or promotional exercise in the private sector or in the government sector a means of improving political standing. Is the information in these programs accurate and independent? What is the appropriate training for financial education providers? Should there be quality standards and codes of conduct for providers of freely accessible financial education programs? Further, what new if any solutions are on the horizon for improving financial education and literacy? Likewise, should we regulate financial education and literacy programs? Lastly, is it feasible at all to evaluate universal changes in school curricula aimed at improving financial literacy where the outcomes will only be realised over very long periods, even if this did matter to government stakeholders? Clearly, much remains unknown.

As to the implications for financial services marketing, it is clear that financial literacy programs are useful for financial institutions dealing with their stakeholders, including current and potential customers. These need to consider whether they target specific groups (children, retirees and the elderly, the Indigenous, etc.) or the population, address particular themes (budgeting, investment, savings, etc.) or a combination of themes. They also need to 
decide whether they team with a community and/or government body for this purpose, and whether they deliver education as a self-paced or structured program, and whether they deliver in in-person, in hardcopy, or through the web.

\section{CONCLUSION}

Scarcely a decade ago, almost nothing was known about financial literacy in Australia. Now more than half a dozen major reports and a score of smaller research projects have been completed, all of which have identified the pressing need for improvements in financial literacy for the Australian population as whole and for several population subgroups, particularly women, the Indigenous, those from non-English speaking backgrounds, lowincome workers, the unemployed, and the young. In response, a large number of government departments and agencies, businesses and business associations, community groups and workplaces have designed and funded financial literacy programs, many targeted at these financially less literate groups. At the same time, a national financial literacy strategy has been created with a single financial regulator given responsibility for its implementation. Feedback on the National Financial Literacy Strategy coordinated by ASIC (2013) will certainly provide insight into this area.

With the many and varied financial literacy stakeholders in mind, this paper reviewed the existing findings on financial literacy in Australia, along with its purported determinants and the potential impact on consumers and the marketing of financial services. The paper also sampled many of the financial literacy programs set in place by government, industry, community, and workplace initiatives. Clearly, there is much work required of the many and diverse financial literacy stakeholders in both areas. In terms of the measurement of financial literacy, there is a need for on-going research, especially in terms of attempting to agree upon a suitable framework and method for its assessment. As for financial literacy programs, these continue to grow and expand and a periodic review would help stakeholders understand what is being done and not being done in this important area. However, once again, there are some limitations in this area, and they likewise indicate future opportunities for research, particularly as they relate to optimal program design and evaluation.

\section{REFERENCES}

10thousandgirl (2013) How 10thousandgirl works. http://www.10thousandgirl.com/some-facts/how-10thousandgirl-works/, accessed 17 June 2013.

ANZ (with Roy Morgan Research) (2003) ANZ Survey of Adult Financial Literacy in Australia. Melbourne: ANZ. http://www.thesmithfamily.com.au/webdata/resources/files/ANZreportMay03.pdf, accessed 17 June 2013.

ANZ (with AC Nielsen) (2005) ANZ Survey of Adult Financial Literacy in Australia. Melbourne: ANZ. http://www.anz.com.au/aus/aboutanz/Community/Programs/pdf/ANZ_Survey_2005.pdf, accessed 17 June 2013. 
ANZ (with Roy Morgan Research) (2011) Adult Financial Literacy in Australia. Melbourne: ANZ. http://www.anz.com.au/resources/3/d/3dbcd380493e8b9395e5d7fc8cff90cd/2011-Adult-Financial-LiteracySummary.pdf.pdf?CACHEID=3dbcd380493e8b9395e5d7fc8cff90cd, accessed 17 June 2013.

ANZ (with Social Research Centre) (2008). ANZ Survey of Adult Financial Literacy in Australia. Melbourne: ANZ. http://www.anz.com/Documents/AU/Aboutanz/AN_5654_Adult_Fin_Lit_Report_08_Web_Report_full.pdf, accessed 17 June 2013.

ANZ (2013) MoneyBusiness. http://www.anz.com.au/about-us/corporate-responsibility/framework/financialcapability/moneybusiness/, accessed 17 June 2013.

Australian Bankers' Association (2013) ABA's financial literacy program. http://www.bankers.asn.au/Consumers/FinancialLiteracy, accessed 17 June 2013.

Australian Curriculum, Assessment and Reporting Authority (2013) Australian curriculum. http://www.australiancurriculum.edu.au, accessed 17 June 2013.

Australian Curriculum, Assessment and Reporting Authority (2013) Draft Shape of the Australian Curriculum: Economics and Business. Sydney: ACARA. http://www.acara.edu.au/verve/ resources/Draft Shape Paper for consultation _Economics_and_Business.pdf, accessed 17 June 2013.

Australian Defence Force Financial Services Consumer Council (2013) About us. http://www.adfconsumer.gov.au/aboutus/charter/, accessed 17 June 2013.

Australian Law Reform Commission (2005). Seen and heard. http://www.austlii.edu.au/au/, accessed 29 January 2013.

Australian Securities and Investments Commission (2005) Financial Literacy in Schools. Sydney: ASIC. http://www.asic.gov.au/asic/pdflib.nsf/LookupByFileName/FinLit_schools_DP.pdf/\$file/FinLit_schools_DP.pdf, accessed 17 June 2013).

Australian Securities and Investments Commission (2011a) Financial Literacy and Behavioural Change, Report 230, Sydney: ASIC. http://www.asic.gov.au/asic/pdflib.nsf/LookupByFileName/rep230-financial-literacy-and-behaviouralchange.pdf/\$file/rep230-financial-literacy-and-behavioural-change.pdf, accessed 29 January 2013.

Australian Securities and Investments Commission (2011b) National Financial Literacy Strategy. Sydney: ASIC. Report 229. http://www.financialliteracy.gov.au/media/218312/national-financial-literacy-strategy.pdf, accessed 29 January 2013.

Australian Securities and Investments Commission (2012) Update on ASIC's MoneySmart Project. Syndey: ASIC. www.financialliteracy.gov.au/media/398500/moneysmartreport-2012.doc, accessed 29 January 2013.

Australian Securities and Investments Commission (2013) Shaping a National Financial Literacy Strategy for 2014-16: Consultation Paper. Sydney: ASIC. http://www.financialliteracy.gov.au/media/424937/shaping a national financial literacy strategy for 2014$\underline{16 \_ \text {consultation_paper.pdf }}$, accessed 17 June 2013.

Bateman, H., Eckert, C., Geweke, J., Louiviere, J., Thorp, S. and Satchell, S. (2012) Financial competence and expectations formation: Evidence from Australia. The Economic Record 88(280): 39-63.

Beal, D.J. and Delpachtra, S.B. (2003) Financial literacy among Australian university students. Economic Papers 22(1): 6578.

Blanton, K. (2011) Financial Literacy on the Web. Boston: Centre for Retirement Research. http://crr.bc.edu/wpcontent/uploads/2012/04/Financial-Literacy-on-the-web.pdf, accessed 17 June 2013.

Brotherhood of St. Laurence (2011) Many Faces of Saving: The Social Dimensions of Saver Plus. Melbourne: Brotherhood of St. Lawrence. http://www.bsl.org.au/pdfs/Bodsworth_Many_faces_of_saving_2011.pdf, accessed 29 January 2013.

Brown, K. Gallery, N. and Gallery G. (2004) Informed superannuation choice: Constraints and policy resolutions. Economic Analysis and Policy 32(1): 71-90.

Cardak, B.A. and Wilkins, R. (2009) The determinants of household risky asset holdings: Australian evidence on background risk and other factors. Journal of Banking and Finance 33(5): 850-860.

Canadian Bankers Association (2005) Building a better understanding. http://www.cba.ca/, accessed 29 January 2013.

Citi Australia (with The Australia Institute) (2010) Evidence versus Emotion: How Do We Really Make Financial Decisions? Sydney: Citi Australia. http://www.citi.com.au/citigroup/pdf/Citi_Fin_Report_full_document.pdf, accessed 29 January 2013.

Citizen's Advice Bureaux (2013) http://citizensadvice.org.uk/ (accessed 29 January 2013).

Commonwealth Bank Foundation (with Eureka Strategic Research and the Centre of Policy Studies) (2004) Improving Financial Literacy in Australia: Benefits for the Individual and the Nation. Sydney: Commonwealth Bank Foundation. http://www.commbank.com.au/about-us/download-printed-forms/FinancialLiteracy_KeyFindingst2004.pdf, accessed 29 January 2013.

Commonwealth Bank Foundation (2006) Australian Financial Literacy Assessment Report. Sydney: Commonwealth Bank Foundation. http://www.commbank.com.au/about-us/download-printed-forms/AFLA-2005-report.pdf, accessed 29 January 2013.

Consumer and Financial Literacy Taskforce (2004) Australian consumers and money. http://www.cfltaskforce.treasury.gov.au/, accessed 29 January 2013.

Consumer Bankers Association. (2005) Surveys on Bank-sponsored Financial Literacy Programs. Washington D.C.: Consumer Bankers Association. http://www.faircredit.org/files/57.pdf, accessed 29 January 2013.

Consumer Financial Education Body (2013) http://www.moneymadeclear.org.uk/, accessed 29 January 2013. 
Croy, G., Gerrans, P. and Speelman, C. (2010) The role and relevance of domain knowledge, perceptions of planning importance, and risk tolerance in predicting savings intentions. Journal of Economic Psychology 31(6): 860-871.

Davidson Institute (2013) Westpac financial education: Financial first steps. https://www.davidsoninstitute.edu.au/, accessed 29 January 2013.

Department of Families, Housing, Community Services and Indigenous Affairs (2013a) Family income management. http://www.fahcsia.gov.au/, accessed 29 January 2013.

Department of Families, Housing, Community Services and Indigenous Affairs (2013b) Financial management program. http://www.fahcsia.gov.au/, accessed 29 January 2013.

Department of Families, Housing, Community Services and Indigenous Affairs (2013c) Indigenous home ownership program. http://www.fahcsia.gov.au/, accessed 29 January 2013.

Department of Human Services (2013) Financial information service. http://www.humanservices.gov.au/, accessed 29 January 2013.

Enterprise New Zealand Trust (2005) What Enterprise New Zealand Trust does. http://enzt.co.nz/

Financial Basics Foundation (2013) Earning, saving, spending, investing. http://www.essimoney.com.au/, accessed 29 January 2013.

Financial Consumer Agency of Canada (2013) http://www.fcac-acfc.gc.ca, accessed 29 January 2013.

Financial Literacy Foundation (2007) Financial Literacy: Australians Understanding Money. Canberra: Commonwealth of Australia. http://www.financialliteracy.gov.au/media/209293/australians-understanding-money.pdf, accessed 29 January 2013.

Financial Literacy Foundation (2008) Financial literacy: Women understanding money, Commonwealth of Australia, Canberra, http://www.financialliteracy.gov.au/ (accessed 29 January 2013).

Fry, T.R., Mihajilo, S., Russell, R. and Brooks, R. (2008) The factors influencing saving in a matched savings program: Goals, knowledge of payment instruments, and other behaviour. Journal of Family and Economic Issues 29(2): 234250

Gale, W. G and Levine, R. (2010) Financial Literacy: What Works? How Could It Be More Effective? Santa Monica: RAND. http://www.rand.org/content/dam/rand/www/external/events/2010/11/18/financial-literacy-what-works.pdf, accessed 6 February 2013.

Gallery, N., Newton, C. and Palm, C. (2011) Framework for assessing financial literacy and superannuation investment choice decisions. Australasian Accounting Business and Finance Journal, 5(2): 3-22.

Garman, E.T., Kim, J., Kratzer, C.Y., Brunson, B.H., and Joo, S.H. (1999) Workplace financial education improves personal financial wellness. Financial Counselling and Planning Journal 10(1): 79-99.

Gerrans, P., Clark-Murphy, M. and Truscott, K. (2009) Financial literacy and superannuation awareness of indigenous Australians: Pilot study results. Journal of Social Issues 44(4): 417-439.

Good Shepherd Youth and Family Service (2013) Dollars n' sense. http://www.goodshepvic.org.au/, accessed 29 January 2013.

Jumpstart Coalition for Personal Financial Literacy (2013) http://www.jumpstart.org/, accessed 29 January 2013.

Makingcents (2013) http://www.makingcents.com.au/, accessed 29 January 2013.

Marcolin, S and Abraham, A, Financial literacy research: Current literature and future opportunities. Proceedings of the 3rd International Conference on Contemporary Business Conference, Leura NSW; 21-22 September 2006. http://ro.uow.edu.au/commpapers/223, accessed 29 January 2013/

Mercer Australia (2011) Mercer superannuation sentiment index study: Wave 2011. http://securingretirementincomes.com.au/, accessed 29 January 2013.

MoneySmart (2013) Money Smart Week. https://www.moneysmart.gov.au/, accessed 29 January 2013.

MoneySmart Teaching (2013) https://www.teaching.moneysmart.gov.au/, accessed 29 January 2013.

Moneywise Global (2013) Flight Centre http://www.moneywiseglobal.com/, accessed 29 January 2013.

National Australia Bank (2013) Indigenous Australia. http://www.nab.com.au, accessed 29 January 2013.

National Australia Bank (with Centre for Social Impact) (2011) Measuring Financial Exclusion in Australia. Syndey: NAB. http://www.csi.edu.au/assets/assetdoc/3c1698bd3334ed55/NAB-Financial-Exclusion-Report_Final.pdf, accessed January 2013.

New Zealand Retirement Commission (2013) Sorted: Your independent money guide. https://www.sorted.org.nz/, accessed 29 January 2013.

OECD (2005). Improving Financial Literacy: Analysis of Issues and Policies. Paris: OECD.

OECD (2012a) High-level Principles on National Strategies for Financial Education. Paris: OECD.

OECD (2012b) Programme for International Student Assessment PISA 2012: Financial Literacy Assessment Framework. Paris: OECD. http://www.oecd.org/pisa/pisaproducts/46962580.pdf, accessed 29 January 2013.

OECD (2013) International gateway for financial education http://www.financial-education.org/, accessed 29 January 2013.

Personal Finance Education Group (2013) About pfeg. http://pfeg.org/ , accessed 29 January 2013.

Russell, R., Wall, L. and Doan, M.P. (2011) Evaluation of Saver Plus Past Participants. Melbourne: RMIT University. http://www.anz.com.au/resources/9/8/984a238048778b6e92a7fe023b6064b7/2011-RMIT-Saver-Plus-Evaluation-PastParticipants.pdf.pdf?CACHEID=984a238048778b6e92a7fe023b6064b7, accessed 29 January 2013. 
Russell, R. Wall, L. and Doan, M.P. and Bodsworth, E. (2011) Saver Plus Summary Report 2011. Melbourne: Brotherhood of St. Lawrence. http://www.bsl.org.au/pdfs/SaverPlus_evaluations_summary_report_2011.pdf, accessed 29 January 2013.

Samy M., Tawfik, H., Huang, R and Nagar, A. K. (2008) Financial literacy of youth: A sensitivity analysis of the determinants. International Journal of Economic Sciences and Applied Research 1 (1): 55-70.

Sandlant, R. (2011) Consumer financial protection: Future directions. JASSA 4: 42-47.

Schagen, S. and Lines, A. (1996) Financial Literacy in Adult Life: A Report to the Natwest Group Charitable Trust, Slough: National Foundation for Educational Research.

StartSmart (2013) http://www.startsmart.com.au/, accessed 29 January 2013.

Taylor, S. and Wagland, S. (2011) Financial literacy: A review of government policy and initiatives. Australasian Accounting Business and Finance Journal 5(2): 101-125.

Tennant, J., Wright, B. and Jackson, J. (2009) Financial hardship and financial literacy: A case study from the Gippsland Region. JASSA 2: 10-15.

U.S. Department of Treasury (2012) Financial Literacy and Education Commission. http://www.treasury.gov/, accessed 29 January 2013.

Wagland, S.P. and Taylor, S. (2009) When it comes to financial literacy, is gender really an issue? Australasian Accounting Business and Finance Journal 3(1): 13-24.

Worthington, A.C. (2006) Predicting financial literacy in Australia, Financial Services Review 15(1): 59-79.

Worthington, A.C. (2008) Knowledge and perceptions of superannuation in Australia. Journal of Consumer Policy 31(3): 349-368.

Xu, L. and Zia, B. (2012) Financial Literacy around the World: An Overview of the Evidence with Practical Suggestions for the Way Forward. Washington D.C. The World Bank. http://wwwwds.worldbank.org/external/default/WDSContentServer/IW3P/IB/2012/06/27/000158349_20120627090058/Rendered/ PDF/WPS6107.pdf, accessed 17 June 2013. 